\title{
THE PROTECTIVE EFFECT OF CARNOSINE ON KIDNEYS OF ALBINO RATS IN METHOTREXATE INDUCED OXIDATIVE INJURY
}

\author{
Mohamed Adly; Ahmed Elshatory; Hanaa Elzahed; George N.B. Morcos* \\ Department of Forensic Medicine and Clinical Toxicology, Faculty of Medicine, Cairo \\ University \\ *Department of Medical Biochemistry \& Molecular Biology, Faculty of Medicine, Cairo \\ University
}

\begin{abstract}
Objective: This study aimed to determine the anti-oxidant effect of carnosine in methotrexate (MTX) induced nephrotoxicity in albino rats. Materials \& Methods: 40 male albino rats are used in this study and were equally divided into four groups. The negative control group received only saline orally, while the positive control group received carnosine $(5 \mathrm{mg} / \mathrm{kg})$ orally for 7 days. On the other hand the MTX group received a single dose $(20 \mathrm{mg} / \mathrm{kg})$ MTX intraperitoneally. The MTX+ carnosine group received the same doses of MTX and carnosine. On the seventh day, blood samples and kidney tissues were obtained for assessment of biochemical markers of the kidney, oxidative stress markers, and histopathological examination. Results: MTX group compared with the control groups (both negative and positive) and the MTX + carnosine group showed significant higher values of both BUN and serum creatinine. This significance was found between MTX group and all other studied groups for BUN levels; and between the MTX group and only the control groups for creatinine levels. The serum superoxide dismutase (SOD) levels were relatively higher in MTX than the other groups while the serum malonedialdehyde (MDA) was significantly higher in the MTX group compared to the other groups. Histopathological examination of the renal tissues showed glomerulosclerosis, marked damage of renal tubules, proteineous material in the renal tubules, and marked cellular infiltration in MTX group. Conclusion \& Recommendations: MTX administration involves oxidative stress causing structural and functional damage in albino rats' kidney tissue. Carnosine administration reduced the MTX-induced oxidative stress and nephrotoxicity through its antioxidant properties. Carnosine may be regarded as a promising agent to alleviate MTX-induced renal toxicity.
\end{abstract}

KEYWORDS: methotrexate, carnosine, nephrotoxicity, oxidative stress.

\section{INTRODUCTION}

Methotrexate (MTX) is used as an anti-cancer drug in higher doses such as acute lymphoblastic leukemia, lymphoma, carcinoma of the breast, osteogenic sarcoma, and cancer of the head and neck region (Choudhury et al., 2000; Miyazaki et al., 2003; Findlay et al., 2008; D'Adamo, 2011). However, lower doses of methotrexate have been used in the treatment of rheumatic diseases due to its immunosuppressant effect (Gisondi and Girolomoni, 2007; and Renna, 2014).

MTX depletes folic acid thus affecting the purine metabolism which is responsible for both therapeutic and toxic effects of MTX. The use of MTX is associated with deleterious effects on 
different organs such as the kidney, liver, testis and bone marrow. As MTX is mainly eliminated through the kidneys nephrotoxicity is more common to occur more than other side effects which limits its therapeutic uses in many condition (Lameire et al., 2011).

The mechanism of renal toxicity has been attributed to direct toxic effect of MTX as well as reactive oxygen species (ROS) production (Widemann \& Adamson, 2006; Wiczer et al., 2016; and Famurewa et al., 2017). Recently, MTX-induced nephrotoxicity has been regarded as a result of oxidative stress (Devrim et al., 2005; Asvadi et al., 2011). Acute renal failure and nephrotoxicity have been reported with the usage of MTX apecially in high doses (Hempel et al., 2003).

Carnosine ( $\beta$-alanyl-l-histidine)

was discovered in 1900 as an abundant non-protein nitrogen-containing compound of skeletal muscle and nervous tissue. The physiological roles of carnosine has been linked to its biochemical properties include $\mathrm{pH}$ buffering, antioxidant capacity and its potential to protect against formation of lipid oxidation end-products (Boldyrev et al., 2013).

For these reasons, the therapeutic potential of carnosine supplementation has been tested in numerous diseases in which oxidative stress is involved. Furthermore, it has been used in physiological states accompanied by oxidative stress and showed promising preclinical and clinical results (AhshinMajd et al., 2016; Prokopieva et al., 2016; and Yamashita et al., 2018).

This study is designed to assess the protective properties of carnosine on methotrexate induced nephrotoxicity. This was carried through the evaluation of both biochemical and histopathological parameters with special focus on the antioxidant status and lipid peroxidation product (MDA)

\section{MATERIALS \& METHODS}

Experimental condition

All the experimental animals used in this study received humane care according to the guidelines outlined in the "Guide for the Care and Use of Laboratory Animals" by the National Institute of Health (NIH). The experimental protocol for the use of live animals in this study was approved by Louisiana State University Institutional Animal Care and Use Committee.

Forty male, albino rats, weighing of 200-220 gm aged 3 months were provided from animal laboratory and used in this experiment. All animals maintained at a constant temperature $\left(30+/-3{ }^{\circ} \mathrm{C}\right)$ in a controlled room where light/dark cycle was maintained. The rats had free access to food and water. Animals were left for 7 days for acclimatization the then distributed randomly into four groups each consisted of ten rats:

(I) Negative Control group: rats in this group received physiological saline by oral gavage for 7 days.

(II) Positive control group: rats in this group received $5 \mathrm{mg}$ carnosine/kilogram (kg) dissolved in distilled water (Nagai \& Suda, 1988). (Sigma chemical Co., Poole, Dorset, U.K.)

(III) MTX group: rats in this group received $20 \mathrm{mg} / \mathrm{kg}$ MTX intraperitoneally (i.p.) in a single dose on the first day and saline by oral gavage for 7 days (Çakir et al., 2015). (Ebewe pharma, Vienna, Austria)

(IV) MTX \& carnosine group: rats in this group received $20 \mathrm{mg} / \mathrm{kg}$ 
MTX (i.p.) in a single dose on the first day and carnosine by oral gavage for 7 days.

At the end of the seventh day, all the experimental rats were anesthetized and euthanized by decapitation. Blood samples were collected for estimation of biochemical parameters and both kidneys were quickly removed and fixed in $10 \%$ neutral formalin solution for histopathological examinations.

\section{Biochemical analysis}

Blood samples were collected and left at room temperature for 10 minutes before centrifugation to separate the serum and then aliquoted for analysis. Serum creatinine and blood urea nitrogen (BUN), in addition to serum superoxide dismutase (SOD) and serum malondialdehyde (MDA) were studied.

1 - Serum creatinine and blood urea nitrogen (BUN) levels were measured using a colorimetric method, employing commercial kits by an auto analyzer.

2- Determination of serum superoxide dismutase (SOD) activity an indicator of antioxidant response, which was analyzed primarily based on reduction of nitroblue tetrazolium (NBT) compound. Activity of the enzyme was expressed as units per milliliter of plasma (Sun et al., 1988).

3- Determination of serum malondialdehyde (MDA) levels were measured with the thiobarbituric acid reaction according to Dahle's method using spectrophotometer and MDA levels were expressed in nanomoles per milliliter (Dahle et al., 1962).

Histopathological analysis

Kidney samples were fixed in $10 \%$ buffered formalin, embedded in paraffin and then cut at 4-5 microns thickness. The cut sections were then stained with hematoxylin and eosin (HE) to be examined by light microscopy. Histopathological changes were diagnosed in a blinded manner by a specialized pathologist unaware of the study groups. Glomerulosclerosis, degeneration of tubular epithelium, presence of proteinous material in the lumen of renal tubules, and presence of inflammatory reaction were evaluated according to the severity of lesions using a $0-3$ scoring system, where $0=$ normal; $1=$ normal glomeruli and slight degeneration in tubular epithelial cells, mild inflammatory reaction; 2= moderate glomerulosclerosis \& tubular degeneration, deposition of proteneous material and moderate inflammatory reaction; $3=$ severe glomerulosclerosis \& tubular degeneration, extensive proteinous material in tubular lumen, and severe inflammatory reaction.

\section{Statistical analysis}

The collected data were tabulated and analyzed using SPSS version 22 software (Spss Inc, Chicago, ILL Company). Quantitative data were expressed as mean \pm standard deviation. ANOVA was used as tests of significance. Significant ANOVA and Krauskal Wallis were followed by post -hoc test to detect significant pairs. The accepted level of significance in this work was stated at $0.05(\mathrm{P}<0.05$ was considered significant).

\section{RESULTS}

\section{Biochemical results}

The mean value \pm SD of BUN levels was higher in the methotrexate group (group III) compared with all other groups in this study and the probability value was found highly significant $(\mathrm{P}<0.0001)$ as shown in table 1. This significance was further studied by post-hoc test and the significance was found between group III and all other studied groups as shown in table 2. Similarly, the mean value $\pm \mathrm{SD}$ of the serum creatinine levels was higher in the group III 
compared with all other studied groups and the probability value was also found highly significant $(\mathrm{P}<0.0004)$ as shown in table 3 . This significance was found only between group III and both the control groups (group I and group II) as shown in table 4.

As regard the serum value \pm SD of SOD enzyme activity levels was relatively higher in group III than the other studied groups. However, the probability value was insignificant $(\mathrm{P}>0.05)$ as shown in table 5. On the other hand, the serum value $\pm \mathrm{SD}$ of MDA level in group III was significantly higher than all other groups in this study $(\mathrm{P}<0.0001)$ as shown in table 6 . This significance was further studied by post-hoc test which showed significance pairwise comparison between every group and each other $(p<0.0001)$.

Histopathological results

The gross examination of the kidneys between the different studied groups did not show any significant difference. Normal renal architecture i.e. glomeruli and renal tubules (histopathological score $=0$ ) was observed in both negative and positive control groups. On the other hand, the MTX group showed glomerulosclerosis, renal tubular damage, proteineous material in the renal tubules, and infiltration by inflammatory cells that ranged between moderate to marked (histopathological score ranged between 2 - 3). Lastly, the MTX + carnosine showed relatively normal kidneys i.e. mild glomeruli and renal tubular degeneration, no proteneous materials in the lumen of the tubules, and mild inflammatory reaction (histopathological score ranged between $0-1)$. The histopathological results in MTX group were significant with both control groups and also the MTX + carnosine group.

Table (1): The mean values of BUN levels (mg/dl) in all studied groups

\begin{tabular}{|l|l|l|l|}
\hline & Mean \pm S.D & F test (one way anova) & P value \\
\hline Negative Control group & $20.9 \pm 1.45$ & \multirow{2}{*}{10.61} & $0.0001^{*}$ \\
\cline { 1 - 2 } Positive control group (Carnosine) & $18.9 \pm 2.32$ & & (HS) \\
\cline { 1 - 2 } Methotrexate group & $26.8 \pm 4.92$ & & \\
\cline { 1 - 2 } Methotrexate + carnosine group & $20.2 \pm 3.81$ & & \\
\hline
\end{tabular}

*(HS) highly significant results.

Table (2): Post-hoc test for the mean values of BUN levels

\begin{tabular}{|l|l|l|l|l|}
\hline & $\begin{array}{l}\text { Negative } \\
\text { Control group }\end{array}$ & $\begin{array}{l}\text { Positive control } \\
\text { group } \\
\text { (Carnosine) }\end{array}$ & $\begin{array}{l}\text { Methotrexate }+ \\
\text { carnosine group }\end{array}$ & $\begin{array}{l}\text { Methotrexate } \\
\text { group }\end{array}$ \\
\hline $\begin{array}{l}\text { Methotrexate } \\
\text { group }\end{array}$ & $0.002 *$ & $0.000^{*}$ & $0.006^{*}$ & \\
\hline \multicolumn{3}{|c}{$*$ significant }
\end{tabular}


Table (3): The mean values of serum creatinine levels $(\mathrm{mg} / \mathrm{dl})$ in all studied groups

\begin{tabular}{|c|c|c|c|}
\hline & Mean \pm S.D & $\begin{array}{c}\text { F test (one } \\
\text { way anova) }\end{array}$ & P value \\
\hline Negative Control group & $0.57 \pm 0.02^{*}$ & & \multirow{2}{*}{5.3} \\
\cline { 1 - 2 } Positive control group (Carnosine) & $0.56 \pm 0.12 \#$ & & \\
Methotrexate group & $0.66 \pm 0.02$ & & \\
\hline Methotrexate + carnosine group & $0.59 \pm 0.01$ & & \\
\hline
\end{tabular}

*(HS) highly significant results.

Table (4): Post-hoc test for the mean values of serum creatinine levels

\begin{tabular}{|c|c|c|c|c|}
\hline & $\begin{array}{c}\text { Negative } \\
\text { Control group }\end{array}$ & $\begin{array}{c}\text { Positive control } \\
\text { group (Carnosine) }\end{array}$ & $\begin{array}{c}\text { Methotrexate }+ \\
\text { carnosine group }\end{array}$ & $\begin{array}{c}\text { Methotrexate } \\
\text { group }\end{array}$ \\
\hline $\begin{array}{c}\text { Methotrexate } \\
\text { group }\end{array}$ & $0.02 *$ & $0.005^{*}$ & 0.06 & \\
\hline
\end{tabular}

* = significant

Table (5): The mean values of serum SOD levels (units per milliliter) in all studied groups

\begin{tabular}{|c|c|c|c|}
\hline & Mean \pm S.D & $\begin{array}{c}\text { F test (one way } \\
\text { anova) }\end{array}$ & P value \\
\hline Negative Control group & $689 \pm 21.34$ & & \\
\hline $\begin{array}{c}\text { Positive control group } \\
\text { (Carnosine) }\end{array}$ & $659 \pm 39.71$ & 1.5 & $>0.05$ \\
\hline Methotrexate group & $705 \pm 59.15$ & & \\
\hline $\begin{array}{c}\text { Methotrexate }+ \\
\text { carnosine group }\end{array}$ & $658 \pm 92.51$ & & \\
\hline
\end{tabular}

Table (6): The mean values of serum MDA levels (nanomoles per milliliter) in all studied groups

\begin{tabular}{|c|c|c|c|}
\hline & Mean \pm S.D & $\begin{array}{l}\text { F test(one way } \\
\text { anova) }\end{array}$ & $\mathrm{P}$ value \\
\hline Negative Control group & $11.2 \pm 0.86^{* *}$ & \multirow[t]{4}{*}{108.8} & \multirow[t]{4}{*}{$0.0001 *(\mathrm{HS})$} \\
\hline $\begin{array}{l}\text { Positive control group } \\
\text { (Carnosine) }\end{array}$ & $8.22 \pm 1.61 * *$ & & \\
\hline Methotrexate group & $17.89 \pm 1.02 * *$ & & \\
\hline $\begin{array}{l}\text { Methotrexate }+ \\
\text { carnosine group }\end{array}$ & $11.25 \pm 1.33 * *$ & & \\
\hline
\end{tabular}

*(HS) highly significant results. 


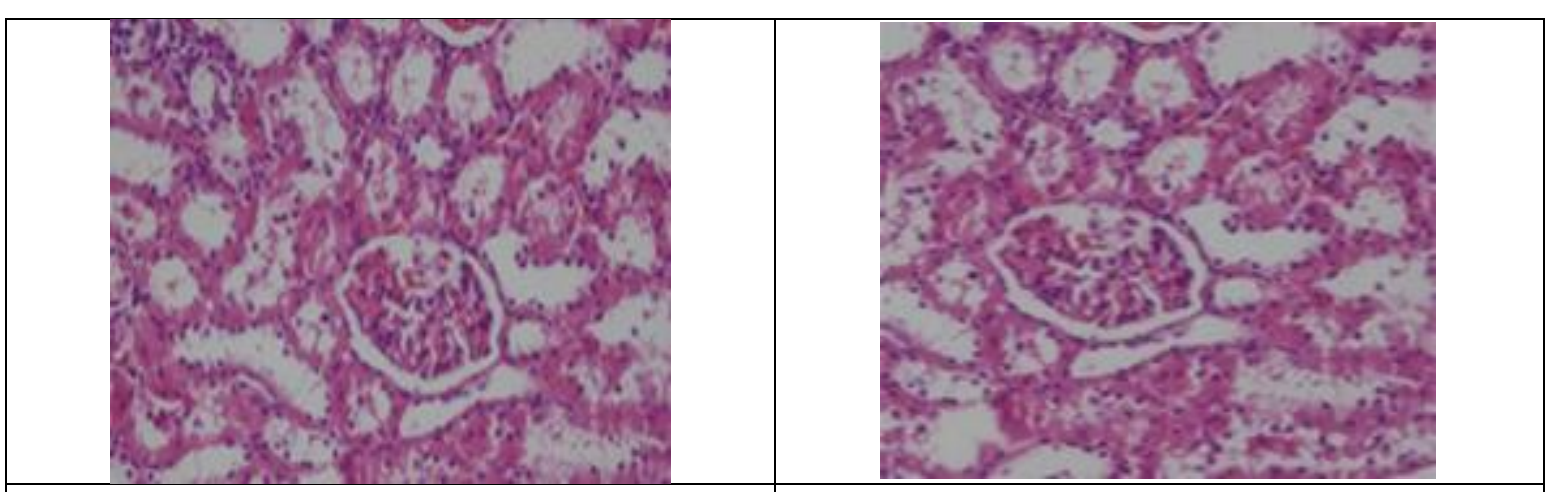

Photomicrograph of renal tissue in Photomicrograph of renal tissue in negative control group (stained with H\&E X 200) showing normal renal tissue $($ score $=0)$ positive control group (stained with 20. H\&E X 200) showing normal renal tissue $($ score $=0)$

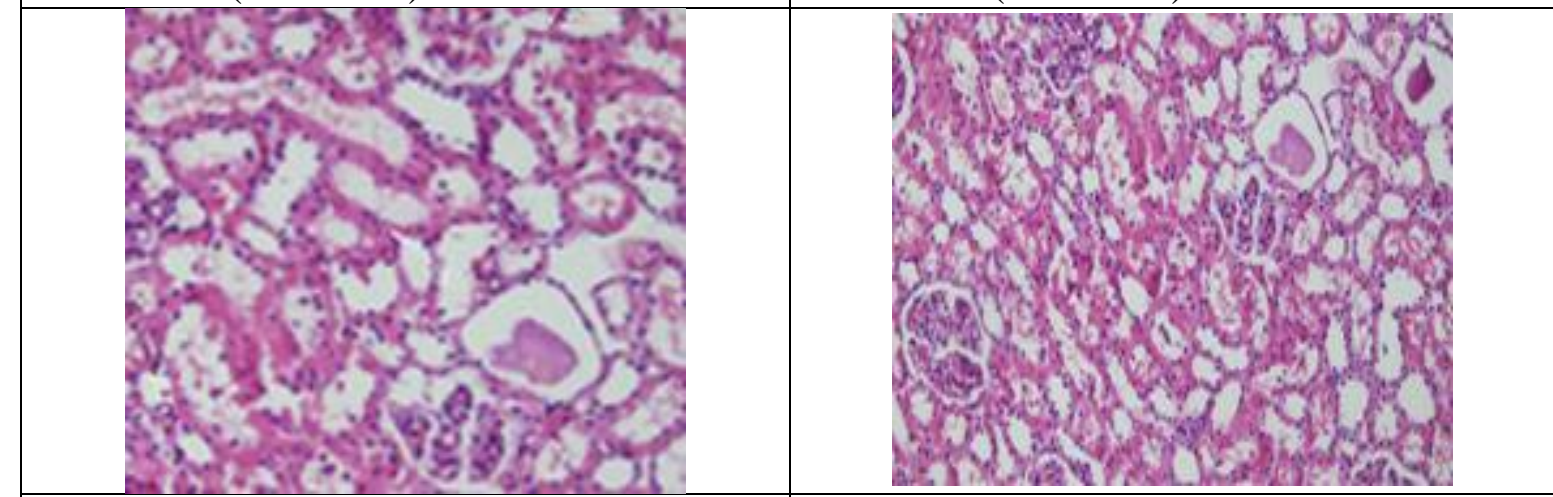

Photomicrograph of renal tissue in MTX group (stained with $\mathrm{H} \& \mathrm{E} X$ 200) showing moderate glomerulosclerosis \& tubular degeneration, proteneous material in the lumen of renal tubules and moderate infiltration with inflammatory cells ( score $=2$ )
Photomicrograph of renal tissue in MTX group (stained with $\mathrm{H} \& \mathrm{E} X$ 200) showing marked glomerulosclerosis, marked tubular degeneration, marked proteineous material in the lumen of renal tubules and marked infiltration by inflammatory cells (score $=3$ )

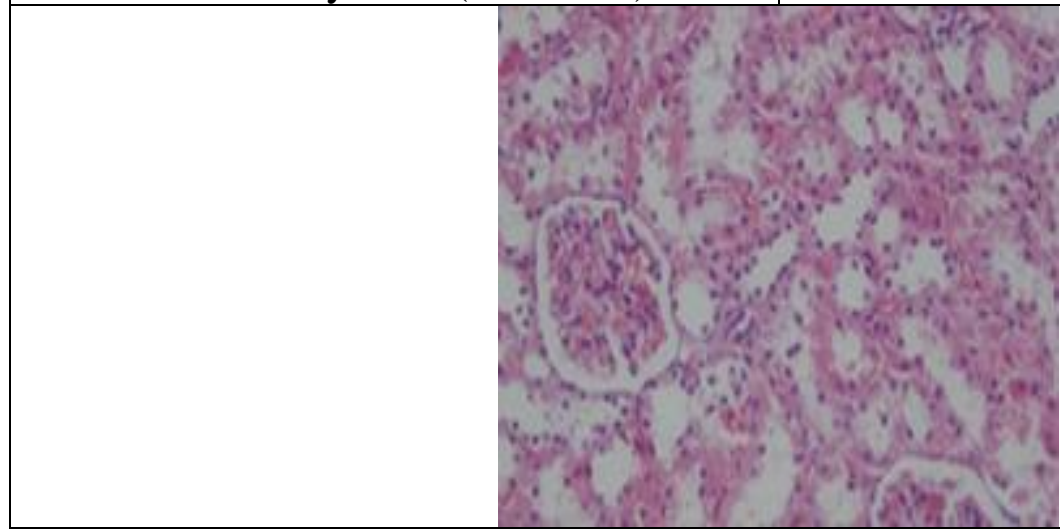

Photomicrograph of renal tissue in MTX+carnosine group (stained with H\&E X 200) showing normal glomeruli, mild tubular degeneration, no proteneous material, mild infiltration with inflammatory cells ( 
Table (7): Statistical analysis of histopathological results of the kidneys

\begin{tabular}{|c|c|c|c|c|c|}
\hline Histopathological analysis & Mean \pm S.D & $\begin{array}{l}\text { Score distribution } \\
\text { per group }\end{array}$ & $\begin{array}{l}\text { Score } \\
\text { range }\end{array}$ & $\mathrm{F}$ test & $\mathrm{P}$ value \\
\hline Negative Control group & $0.00 \pm 0.00$ & 10 rats $=0$ & $0-0$ & \multirow{4}{*}{131.2} & \multirow{4}{*}{$0.0001^{*}$} \\
\hline Positive control group (Carnosine) & $0.00 \pm 0.00$ & 10 rats $=0$ & $0-0$ & & \\
\hline Methotrexategroup & $2.7 \pm 0.48$ & $\begin{array}{l}7 \text { rats }=3 \\
3 \text { rats }=2\end{array}$ & $2-3$ & & \\
\hline Methotrexate + carnosine group & $0.6 \pm 0.52$ & $\begin{array}{l}6 \text { rats }=1 \\
4 \text { rats }=0\end{array}$ & $0-1$ & & \\
\hline
\end{tabular}

*(HS) highly significant results.

Table (8): Post-hoc test for the histopathological results of the kidneys

\begin{tabular}{|l|l|l|l|l|}
\hline & $\begin{array}{l}\text { Negative } \\
\text { Control group }\end{array}$ & $\begin{array}{l}\text { Positive } \\
\text { control group } \\
\text { (Carnosine) }\end{array}$ & $\begin{array}{l}\text { Methotrexate } \\
+ \text { carnosine } \\
\text { group }\end{array}$ & Methotrexate \\
\hline $\begin{array}{l}\text { Methotrexate } \\
\text { group }\end{array}$ & $0.0001^{*}$ & $0.0001^{*}$ & $0.003^{*}$ & \\
\hline
\end{tabular}

\section{DISCUSSION}

Methotrexate (MTX) is a common drug that is used for treatment of many autoimmune diseases using low doses of the drug in addition to treatment of different malignancy using high doses mainly through its anti-inflammatory and anti-proliferative effects.

(Widemann et al., 2004; and Dalaklioglu et al., 2013).

This anti-metabolite drug property of MTX is capable of blocking cell metabolism through the inhibition of tetrafolate enzyme thus preventing synthesis of protein, DNA, RNA, and adenosine triphosphate. This results in difficult cell regeneration and cell death occurs (Jolivet et al., 1983; Mycek et al., 1997; and Miyazono et al., 2004). This mechanism is responsible for both its therapeutic and toxic effects. The severity of MTX toxicity is a dose depending as well as the frequency of administration. Liver, renal, and gastrointestinal damage are common adverse effects. MTX induced renal damage has been regarded a common reason which restricts its therapeutic uses (Tabassum et al., 2010).

MTX induced renal toxicity has been attributed to two mechanisms. The first mechanism is direct by MTX and its metabolite which precipitate in the lumen of renal tubules leading to necrosis. The other mechanism that has been discussed in several studies is the oxidative damage (Babiak et al., 1998; and Vardi et al., 2013). MTX results in increase of reactive oxygen species (ROS) which leads to tissue damage (Babiak et al., 1998).

It is well known that under normal physiological conditions ROS carry out important regulatory functions in the organism (Lin and Beal, 2006; Halliwell and Gutteridge, 2007; and Valko et al., 2007). However, under uncontrolled increase in ROS, they interact with biomolecules, leading to their oxidative modifications. Products 
of such modification usually lose ability to carry out their functions. These products serve as "markers of oxidative stress," and they include carbonylated, nitrosylated, and glycated proteins; aggregates due to cross linking of protein molecules; products of lipid peroxidation such as malondialdehyde. All these products of oxidative damage are resistant to destructions and accumulate in cells affecting their vital functions. Therefore, their neutralization plays an important role in correction of the oxidative stress (Lin and Beal, 2006; and Menshchikova et al., 2006).

Although the human endogenous antioxidant response system can regulate the amount of ROS tightly and minimize related cellular damage (Kensler et al., 2007), the role of exogenous antioxidants is also important. It was found that exogenous antioxidants have a priming effect on the antioxidant response system. The both endogenous antioxidant response system and exogenous antioxidants allow for a more enhanced and efficient defense against detrimental redox modulations (Kensler et al., 2007; and Niture et al., 2014).

Carnosine meets almost all requirements for an ideal antioxidant. It is characterized by being synthesized and contained in human muscle and nervous tissues. It is absorbed from the alimentary tract and has high bioavailability. In addition, carnosine does not carry the danger of overdose nor it accumulates in the organism during administration as it is metabolized by the carnosinase enzyme. This low molecular weight hydrophilic antioxidant acts through its direct action and has also an impact on the antiradical protection system of the organism (Boldyrev, 2009).

Several studies described the positive biological effects by its $\mathrm{pH}$ buffering properties (Skulachev, 1992); buffering reactive oxygen species (Severin et al., 1984); and its ability of to form complexes with bivalent metals such as ions of copper, cobalt, manganese, cadmium (Brown and Antholine, 1979), and iron ions (Vladimirov, 1996). Further, the antiglycating and the anticross-linking properties of carnosine have been shown and are attributed to its antioxidant effects (Hipkiss et al., 1995; and Hobart et al., 2004).

In this study, BUN and creatinine were measured in the four groups as indicators of renal function. The mean value of BUN levels was significantly higher in the methotrexate group (group III) compared with all other studied groups (both control groups and MTX + carnosine group) $(\mathrm{P}<0.0001)$. This was in agreement with Armagan et al., 2015 and Asci et al., 2017 that found similar biochemical findings indicating the impairment of renal function induced by MTX and the protective effect of carnosine.

As regard the serum creatinine the other studied parameter for renal function, it was found that the mean values levels was also significantly higher in the group III compared with all other studied groups $(\mathrm{P}<0.0004)$. However, this significance was found only between group III and both the control groups. Asci et al., 2017 described similar results one side, and on the other side Armagan et al., 2015 stated that serum creatinine levels were significant in MTX group as compared to all other studied groups. 
SOD is an important antioxidant enzyme against the deleterious effects of ROS such as lipid peroxidation (Wang et al., 2007). The serum mean value of SOD activity levels in this study was relatively higher in the MTX group compared with the other studied groups $(\mathrm{P}>0.05)$ which can be attributed to the oxidative damage caused by MTX. In a similar study, Yuksel et al., 2017 showed that both serum and tissues SOD levels were higher in methotrexate group compared with the other studied groups and only the serum SOD was significant. In contrast, Savran et al., 2017 found a significant increase in the serum SOD in the MTX group compared to other groups in their study.

MDA is an indicator of free radical generation and lipid peroxidation (Young et al., 2001). It is also well established that MDA causes protein damage by means of reaction with lysine amino groups, cysteine sulfhydryl groups and histadine imidazole groups. Thus MDA levels forms a useful point for correlation with organ affection (Brunner et al., 1995). Regarding the serum mean value of MDA levels in this study, MTX group exhibited significantly higher levels than all other groups $(\mathrm{P}<0.0001)$. Interestingly, the serum mean value of MDA levels in the carnosine group was significantly lower than the negative control group. This result emphasizes on the protective antioxidant properties even under physiological states. Yuksel et al., 2017 reached the same results denoting the beneficial effects of carnosine in reducing the process of lipid peroxidation resulting from MTX administration.

Histopathological studies showed that the methotrexate group exhibited marked to moderate glomerulosclerosis and renal tubular damage, the renal tubules showed proteineous material, in addition to infiltration by inflammatory cells which ranged between moderate to marked. The renal damage in the MTX group was considered significant as compared with the three other studied groups $(\mathrm{P}<0.0001)$. The administration of carnosine attenuated the renal damage and the renal tissues showed normal renal architecture up to mild glomerulosclerosis, mild tubular damage, and mild inflammatory reaction. Several studies such as Uzar et al., 2006; Asci et al., 2017; Yuksel et al., 2017 showed similar histopathological results indicating the associated oxidative stress in MTX intoxication and the positive potentials of carnosine as a potent antioxidant that protected the renal tissues against the oxidative stress induced by MTX.

\section{CONCLUSION}

The present study demonstrates the renal protective and antioxidant effects of carnosine through acting as a potent scavenger for free radicals and limiting lipid peroxidation

\section{REFERENCES}

Ahshin-Majd S, Zamani S, Kiamari T, Kiasalari Z, Baluchnejadmojarad T, Roghani M. (2016). Carnosine ameliorates cognitive deficits in streptozotocin-induced diabetic rats: Possible involved mechanisms. Peptides; 86:102-111.

Armagan I., Bayram D, Candan I.A., Yigit A., Celik E., Armagan H.H., et al. (2015). Effects of pentoxifylline and alpha lipoic acid on methotrexate-induced damage in liver and kidney of rats. Environ Toxicol Pharmacol;39(3):1122-31. 
Asci H., Ozmen O., Ellidag H. Y., Aydin B., Bas E., Yilmaz N. (2017). The impact of gallic acid on the methotrexateinduced kidney damage in rats. $\mathbf{J}$ Food Drug Anal.;25(4):890-897.

Asvadi I, Hajipour B, Asvadi A, et al (2011). Protective effect of pentoxyfilline in renal toxicity after methotrexate administration. Eur Rev Med Pharmacol Sci, 15, 1003-9.

Babiak RM, Campello AP, Carnieri EG, et al. (1998). Methotrexate: pentose cycle and oxidative stress. Cell Biochem Funct; 16(4): 283293.

Boldyrev A. A. Carnosine-Unraveled Mystery of Nature. Moscow, Russia: IKAR; 2009.

Boldyrev AA, Aldini G, Derave W. (2013) Physiology and pathophysiology of carnosine. Physiol Rev.,93(4):1803-45.

Brown C. E., Antholine W. E. (1979). Chelation chemistry of carnosine. Evidence that mixed complexes may occur in vivo. Journal of Physical Chemistry; 83(26):3314-3319.

Brunner B. A., Jones A. D., German J. B. (1995). Direct characterization of protein adducts of lipid peroxidation product 4-hydroxy-2-nonenal using electrospary spectrometry. Chem. Res. Toxicol.; 8:552-59.

Çakir T, Polat C, Basturk A, Gul M, Aslaner A, et al. (2015). The effect of alpha lipoic acid on rat kidneys in methotrexate induced oxidative injury. European Review for Medical and Pharmacological Sciences ; 19: 2132-2139.

Choudhury RC, Ghosh SK, Palo AK (2000). Cytogenetic toxicity of methotrexate in mouse bone marrow. Environ Toxicol Pharmacol, 3, 1916.
D'Adamo DR (2011). Appraising the current role of chemotherapy for the treatment of sarcoma. Seminars in Oncology, 38, 19-9.

Dahle LK, Hill EG and Holman RT. (1962). The thiobarbituric acid reaction and the autoxidations of polyunsaturated fatty acid methyl esters. Arch Biochem Biophys 1962; 98: 253-261.

Dalaklioglu S, Genc GE, Aksoy NH, et al. (2013). Resveratrol ameliorates methotrexate-induced hepatotoxicity in rats via inhibition of lipid peroxidation. Hum Exp Toxicol; 32(6): 662-671.

Devrim E, Cetin R, Kilicoglu B, et al (2005). Methotrexate causes oxidative stress in rat kidney tissues. Ren Fail, 27, 771-3.

Famurewa AC, Aja PM, Maduagwuna EK, Ekeleme-Egedigwe CA, Ufebe OG, Azubuike-Osu SO. (2017) Antioxidant and anti-inflammatory effects of virgin coconut oil supplementation abrogate acute chemotherapy oxidative nephrotoxicity induced by anticancer drug methotrexate in rats. Biomed Pharmacother.; 96:905-911.

Findlay M, von Minckwitz G, Wardley A (2008). Effective oral chemotherapy for breast cancer: pillars of strength. Ann Oncol, 19, 212-22.

Gisondi P, Girolomoni G (2007). Biologic therapies in psoriasis: a new therapeutic approach. Autoimmun Rev, 6, 515-9.

Halliwell B., Gutteridge J. M. C. Free Radicals in Biology and Medicine. 4th. Oxford, UK: Clarendon Press; 2007.

Hempel L, Misselwitz J, Fleck C, Kentouche K, Leder C, Appenroth D, Rost M, Zintl F. (2003) 
Influence of highdose methotrexate therapy (HDMTX) on glomerular and tubular kidney function. Med Pediatr Oncol.; 40(6):348-54.

Hipkiss A. R., Michaelis J., Syrris P. (1995).

Non-enzymatic glycosylation of the dipeptide 1carnosine, a potential anti-proteincross-linking Letters;371(1):81-85.

Hobart L. J., Seibel I., Yeargans G. S., Seidler N. W. (2004). Anticrosslinking properties of carnosine: significance of histidine. Life Sciences;75(11):1379-1389.

Jolivet J, Cowan KH, Curt GA, et al. (1983). The pharmacology and clinical use of methotrexate. N Engl J Med; 309(18): 1094-1104.

Kensler T. W., Wakabayashi N., Biswal S. (2007). Cell survival responses to environmental stresses via the Keap1-Nrf2-ARE pathway. Annual Review of Pharmacology and Toxicology;47:89-116.

Lameire N, Kruse V, Rottey S (2011). Nephrotoxicity of anticancer drugsan underestimated problem. Acta Clin Belg, 66, 337-45.

Lin M. T., Beal M. F. (2006). Mitochondrial dysfunction and oxidative stress in neurodegenerative diseases. Nature; $\quad 443(7113): 787-$ 795.

Menshchikova E. B., Lankin V. Z., Zenkov N. K. Oxidative Stress. ProOxidants and Antioxidants. Moscow, Russia: Slovo; 2006.

Miyazaki J, Kawai K, Hayashi H, et al (2003). The limited efficacy of methotrexate, actinomycin D and cisplatin (MAP) for patients with advanced testicular cancer. Jpn J Clin Oncol, 33, 391-5.
Miyazono $Y$, Gao $F$ and Horie $T$. (2004). Oxidative stress contributes to methotrexate-induced small intestinal toxicity in rats. Scand $\mathbf{J}$ Gastroenterol; 39(11): 1119-1127.

Mycek MJ, Harvey RA and Champe PC, ed. Lippincott's Illustrated Reviews: Pharmacology, 2nd ed. Philadelphia: Lippincott—Raven, 1997.

Nagai K, Suda T. (1988) Realization of spontaneous healing functions by carnosine and beta alanine on wound healing. Surgery, 100: 815-821.

Niture S. K., Khatri R., Jaiswal A. K. (2014). Regulation of Nrf2-an update. Free Radical Biology and Medicine;66:36-44.

Prokopieva VD, Yarygina EG, Bokhan NA, Ivanova SA. Use of Carnosine for Oxidative Stress Reduction in Different Pathologies. Oxid Med Cell Longev. 2016;2016:2939087.

Renna S, Cottone M, Orlando A (2014). Optimization of the treatment with immunosuppressants and biologics in inflammatory bowel disease. World J Gastroenterol, 20, 9675-90.

Savran M., Cicek E., Doguc D. K., Asci H., Yesilot S., Candan I. A., Dagdeviren B., Cankara F.N., Oncu M., Uğuz A. C., Ozer MK (2017). Vitamin C attenuates methotrexate-induced oxidative stress in kidney and liver of rats. Physiol Int., 29:1-11.

Severin S. E., Boldyrev A. A., Dupin A. M. (1984). Biological role of histidine dipeptides in excitable tissues. Voprosy Medicinskoj Chimii.;3(3):32-36. (Rus).

Skulachev V. P. (1992). Carnosine and anserine as specialised $\mathrm{pH}$-buffershydrogen ions 
transporters. Biohimija;57:13111316. (Rus).

Sun Y, Oberley LW and Li Y. (1988). A simple method for clinical assay of superoxide dismutase. Clin Chem, 34(3): 497-500. 22.

Tabassum H, Parvez S, Pasha ST, et al. (2010). Protective effect of lipoic acid against methotrexate-induced oxidative stress in liver mitochondria. Food Chem Toxicol; 48(7): 1973-1979.

Uzar E, Koyuncuoglu HR, Uz E, Yilmaz HR, Kutluhan S, Kilbas S, Gultekin F. (2006). The activities of antioxidant enzymes and the level of malondialdehyde in cerebellum of rats subjected to methotrexate: protective effect of caffeic acid phenethyl ester. Mol Cell Biochem.; 291(1-2):63-8.

Valko M., Leibfritz D., Moncol J., Cronin M. T. D., Mazur M., Telser J (2007). Free radicals and antioxidants in normal physiological functions and human disease. International Journal of Biochemistry and Cell Biology;39(1):44-84.

Vardi N, Parlakpinar H, Ates B, et al. (2013). The protective effects of Prunus armeniaca L (apricot) against methotrexate-induced oxidative damage and apoptosis in rat kidney. J Physiol Biochem; 69(3): 371-381.

Vladimirov Y. A. Studies of the antioxidant activity by measuring chemiluminescence kinetics. In: Parcker L., Traber M. G., Xin W., editors. Proceedings of the International Symposium on Natural Antioxidants:

Molecular
Mechanisms and Health Effects. Champaign, Ill, USA: CRC Press; 1996. pp. 125-144.

Wang B., Peng L., Zhu L., et al. (2007). Protective effect of total flavonoids from Spirodela polyrrhiza (L.) Schleid on human umbilical vein endothelial cell damage induced by hydrogen peroxide. Colloids Surf B Biointerfaces; 60(1): 36-40.

Wiczer T, Dotson E, Tuten A, Phillips G, Maddocks K. (2016) Evaluation of incidence and risk factors for high-dose methotrexateinduced nephrotoxicity. J Oncol Pharm Pract., 22(3):430-6.

Widemann BC, Adamson PC. (2006) Understanding and managing methotrexate nephrotoxici ty. Oncologist.; 11(6):694-703.

Widemann BC, Balis FM, KempfBielack B, et al. (2004). High-dose methotrexate-induced nephrotoxicity in patients with osteosarcoma. Cancer; 100(10): 2222-2232.

Yamashita S, Sato M, Matsumoto T, Kadooka $\mathrm{K}$, Hasegawa $\mathrm{T}$, Fujimura T, Katakura Y. Mechanisms of carnosine-induced activation of neuronal cells. Biosci Biotechnol Biochem. 2018 Apr;82(4):683-688.

Young I.S., Woodside J. V. (2001). Antioxidants in health and disease. J Clin Pathol; 54(3): 176-186

Yuksel Y, Yuksel R, Yagmurca M, Haltas H, Erdamar H, Toktas M, Ozcan O. (2017). Effects of quercetin on methotrexateinduced nephrotoxicity in rats. Hum Exp Toxicol.;36(1):51-61. 


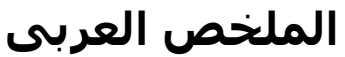

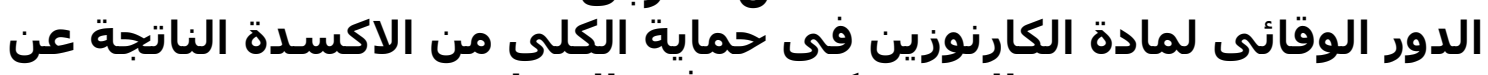

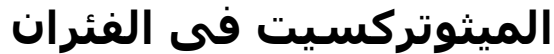

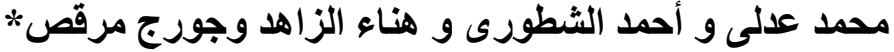

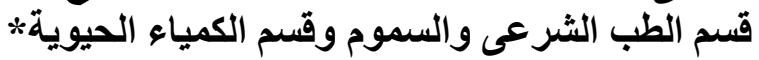 \\ كلية الطب جامعة القاهرة}

تستخدم مادة الميثوتركسيت بجر عات كبيرة فى علاج عدد من السرطانات مثل اللوكيميا و الليمفوما وسرطان

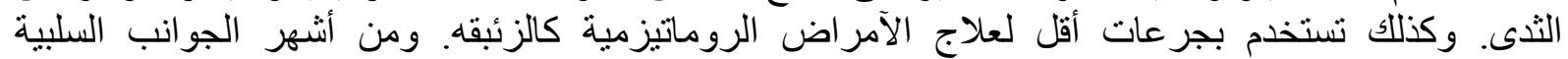

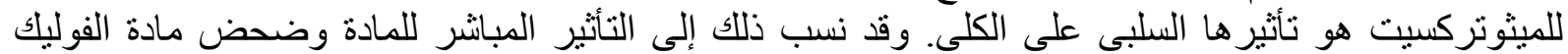

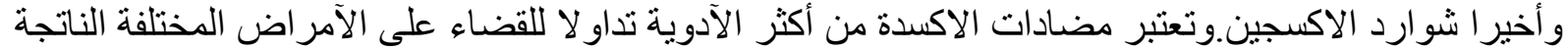

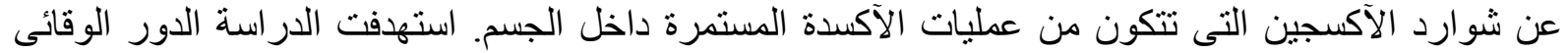

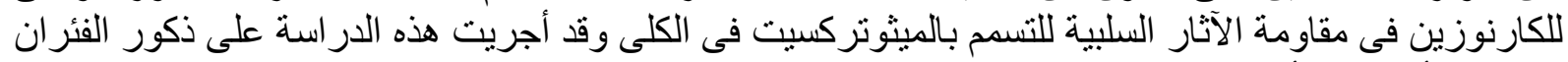

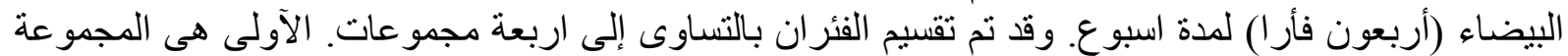

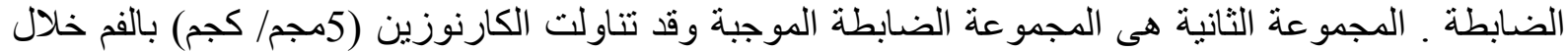

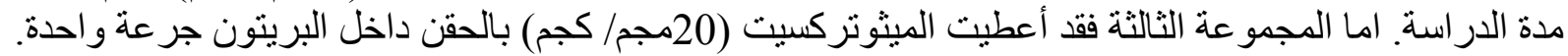

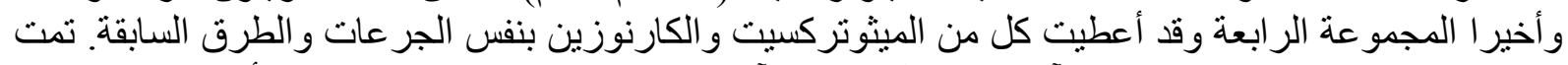

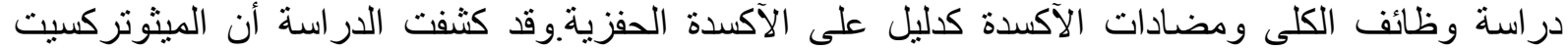

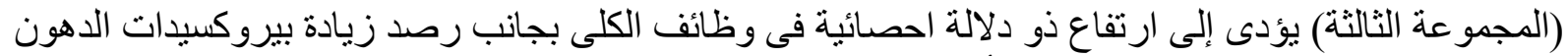

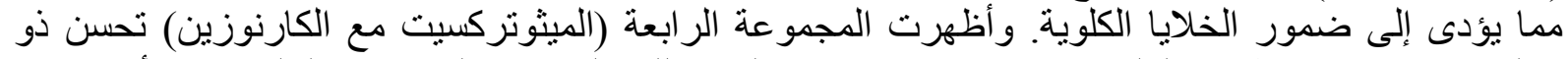

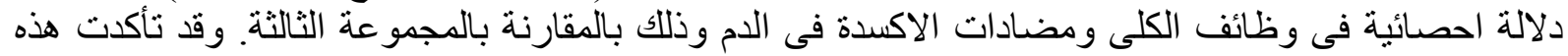

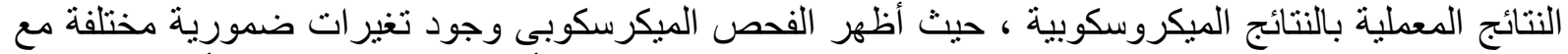

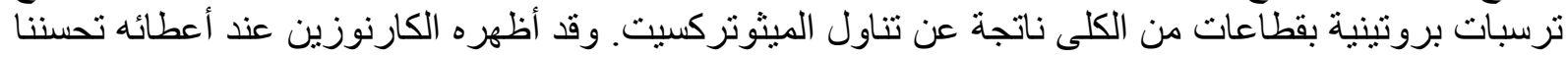

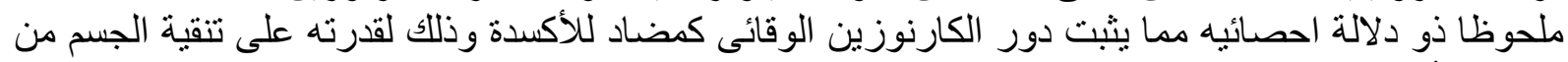

